\title{
FUNGSI BADAN PENGAWAS KEUANGAN DAN PEMBANGUNAN DALAM MELAKUKAN PERHITUNGAN KERUGIAN KEUANGAN NEGARA PADA PERKARA TINDAK PIDANA KORUPSI
}

\author{
Kadek Teguh Aryasa, I Made Minggu Widyantara, Luh Putu Suryani \\ Fakultas Hukum Universitas Warmadewa, Denpasar-Bali, Indonesia \\ teguharyax@gmail.com, mademinggu21@gmail.com putusuryani099@gmail.com
}

\begin{abstract}
Abstrak
Kerugian keuangan Negara merupakan masalah penting untuk dikaji. Tindak pidana korupsi di Indonesia merupakan masalah utama hingga sekarang belum pernah tuntas, mulai dari pusat sampai ke daerah. Hal ini berefek buruk terhadap perkonomian Indonesia. Dalam prakteknya Jaksa Penyidik pada Kejaksaan Negeri Denpasar sering investigasi dalam rangka perhitungan kerugian keuangan Negara. Penelitian ini bertujuan untuk mengetahui legalitas hasil audit investigasi yang dikeluarkan BPKP sebagai alat bukti dalam pembuktian kerugian keuangan Negara pada perkara tindak pidana korupsi dan untuk mengetahui faktor yang mempengaruhi Jaksa Penyidik lebih sering meminta bantuan BPKP untuk melakukan audit investigasi. Metode penelitian yang digunakan adalah penelitian hukum empiris dengan pendekatan kualitatif dan pendekatan deskriptif. Sumber data yaitu data primer yang diperoleh langsung dari Kejaksaan Negeri Denpasar dengan teknik wawancara dan data sekunder dari teori-teori hukum. Hasil penelitian menunjukkan bahwa hasil audit investigasi yang dilakukan oleh BPKP dapat digunakan sebagai alat bukti pada persidangan karena keabsahannya memenuhi unsur- unsur yang terdapat dalam Pasal 184 KUHAP dan kecenderungan Jaksa Penyidik pada Kejaksaan Negeri Denpasar untuk melakukan audit investigasi terhadap Badan Pengawas Keuangan dan Pembangunan disebabkan oleh faktor kebijakan efisiensi dan efektivitas serta faktor sumber daya manusia.
\end{abstract}

Kata Kunci: Badan Pengawasan Keuangan; Kerugian Negara; Tindak Pidana Korupsi

\begin{abstract}
State financial losses are an important issue to study. Corruption in Indonesia is a major problem so far it has never been resolved, starting from the central government to the regions. This has had a bad effect on the Indonesian economy. In practice, the Investigating Prosecutor at the Denpasar District Attorney often conducts investigations in the framework of calculating state financial losses. This study aims to determine the legality of the results of investigative audits issued by the Financial Supervisory Agency as evidence in proving state financial losses in corruption cases and to determine the factors that influence the Investigative Prosecutor to more frequently ask Financial Supervisory Agency for assistance to conduct investigative audits. The research method used is empirical legal research with a qualitative approach and a descriptive approach. The data sources are primary data obtained directly from the Denpasar District Attorney with interview techniques and secondary data from legal theories. The results show that the results of the investigative audit conducted by the Financial Supervisory Agency can be used as evidence at trial because their validity meets the elements contained in Article 184 of the Criminal Procedure Code and the tendency of the Investigative Prosecutor at the Denpasar District Attorney to conduct an investigative audit of the Financial and Development Supervisory Agency efficiency and effectiveness policy factors as well as human resource factors.
\end{abstract}

Keywords: Financial Supervisory Agency; State Losses; Corruption Crime

\section{PENDAHULUAN}

Tindak pidana korupsi modus operandinya sederhana dan ruang lingkup tindak pidana korupsinya sempit, sebagai contoh adanya tindak pidana korupsi dana hibah. Bantuan sosial yang dananya disunat oleh oknum pejabat pemerintah daerah ataupun kegiatan fiktif. Salah satu unsur delik dalam tindak pidana korupsi adalah kerugian keuangan Negara (Romli, 2004). Berdasarkan contoh adanya tindak pidana korupsi dana hibah / bantuan sosial yang dananya disunat oleh oknum pejabat pemerintah daerah ataupun kegiatan fiktif salah satu unsur delik mengatur mengenai siapa yang berhak menghitung kerugian keuangan Negara yang berfungsi untuk memeriksa pengelolaan dan tanggung jawab tentang keuangan negara dengan mendirikan suatu Badan Pemeriksa Keuangan yang bebas dan mandiri (Koswara, 2019). 
Terkait dengan kerugian negara yang ditimbulkan oleh suatu tindak pidana korupsi, UndangUndang Republik Indonesia Nomor 31 Tahun 1999 tentang Pemberantasan Tindak Pidana Korupsi (UUPTPK) telah mengetengahkan konsep pengembalian kerugian keuangan negara. Konsep tersebut diharapkan mampu mengembalikan kerugian negara selain samping pelaku tindak pidana korupsi dikenai sanksi pidana. Juga terdapat sanksi pidana tambahan berupa uang pengganti dengan jumlah sebanyak-banyaknya sama dengan harta benda yang diperoleh dari hasil tindak pidana korupsi (Ferdian et al., 2018). Selanjutnya, pada 23 Oktober 2012 Mahkamah Konstitusi (MK) Putusan yang dalam pertimbangannya pada modus operandinya sederhana dan ruang lingkup tindak pidana korupsinya. Kejaksaan Negeri Denpasar sebagai prakteknya lebih sering investigasi perhitungan sehingga mendalami tentang Fungsi Badan Pengawas Keuangan dan Pembangunan dalam melakukan perhitungan kerugian keuangan negara pada perkara tindak pidana korupsi.

Penelitian sebelumnya mengungkapkan bahwa BPKP berwenang untuk melakukan audit atau penghitungan kerugian keuangan negara termasuk kerugian keuangan negara yang diakibatkan oleh pihak swasta, akan tetapi BPKP tidak berwenang untuk menyatakan (men- declare) adanya kerugian keuangan negara (Permana, 2018). Menurut, Amania, (2016), salah satu unsur yang harus dibuktikan dalam pengungkapan kasus tindak pidana korupsi adalah unsur kerugian negara sebagaimana tertuang dalam Pasal 2 dan 3 Undang-undang No 31 Tahun 1999 jo Undang-undang No 20 Tahun 2001 tentang Pemberantasan Tindak Pidana Korupsi. Penelitian ini bertujuan untuk mengetahui legalitas hasil audit investigasi yang dikeluarkan BPKP sebagai alat bukti dalam pembuktian kerugian keuangan Negara pada perkara tindak pidana korupsi dan untuk mengetahui faktor yang mempengaruhi Jaksa Penyidik lebih sering meminta bantuan BPKP untuk melakukan audit investigasi

\section{METODE PENELITIAN}

Penelitian ini didesain menggunakan metode peneltian yuridis dengan pendekatan perundangundangan. Data penelitian yaitu sumber data primer dan sumber data sekunder (Soerjono \& Mamudji, 2015). Data Primer meliputi data dan wawancara yang berkaitan dengan Tim Pengawal Pengamanan Pemerintahan dan Pembangunan Daerah Kejaksaan Negeri Denpasar sedangkan untuk sumber data sekunder meliputi UUDNRI 1945 UU No 16 tahun 2004 tentang Kejaksaan RI Keputusan Jaksa Agung Nomor KEP-152/A/JA/10/2015 dan Instruksi Jaksa Agung Nomor INS-001/A/JA/10/2015. Teknik pengumpulan data yang dipergunakan yaitu teknik studi kepustakaan melalui data data dokumen dan teknik lapangan yang dilakukan dengan wawancara, selanjutnya data dianalisis secara deskriptif kualitatif.

\section{HASIL DAN PEMBAHASAN}

\section{Legalitas Hasil Audit Investigasi BPKP}

Pengawasan Negara dilakukan untuk menjamin keuangan negara pengumpulan penerimaanpenerimaan Negara dengan bertitik tolak dari nota kesepahaman (MoU) tersebut maka Jaksa Penyidik atas dasar amanat dari pimpinan dalam membuktikan unsur kerugian keuangan negara melakukan koordinasi dan meminta bantuan audit investigasi kepada BPKP (Imron, 2016). Kewenangan BPKP menurut Mahkamah Konstitusi dengan modus operandinya sederhana dan ruang lingkup tindak pidana korupsinya sempit Sebagai contoh adanya tindak pidana korupsi dana hibah/bantuan sosial yang dananya disunat oleh oknum pejabat pemerintah daerah ataupun kegiatan fiktif akibatdari hasil kesepahaman (MoU) tersebut maka Jaksa Penyidik atas dasar amanat dari pimpinan dalam membuktikan unsur kerugian keuangan negara melakukan koordinasi audit investigasi kepada BPKP (Ferry, 2014).

Berdasarkan data mengenai perkara Denpasar yang diambil pada periode waktu tahun 2015 sampai dengan tahun 2020 terdapat 15 yang menggunakan operandinya sederhana dan ruang lingkup tindak pidana korupsinya sempit Sebagai contoh adanya tindak pidana korupsi dana hibah/bantuan sosial yang dananya disunat oleh oknum pejabat pemerintah daerah ataupun kegiatan fiktif. Dengan demikian dapat diartikan bahwa hasil audit investigasi terhadap kerugian negara dapat diakui atas dasar hasil dari pemeriksaan BPKP Dengan bertitik tolak dari nota kesepahaman (MoU) tersebut maka Jaksa Penyidik atas dasar amanat dari pimpinan dalam membuktikan unsur kerugian keuangan negara melakukan koordinasi dan meminta bantuan audit investigasi kepada diakui legalitasnya dan telah menjadi yurisprudensi. Audit investigasi yang dilakukan oleh BPKP keabsahan dari hasil audit yang 
dikeluarkannya termasuk ke dalam kategori dimana hasil audit investigasi memiliki peran sebagai alat bukti surat dan alat bukti ahli.

Sesuai wawancara yang penulis lakukan terhadap Hakim Putu Gde Novyartha Sh M Hum (diwawancarai Rabu 21/10/2020 pukul 1130 WITA) yang mana disebutkan bahwa hasil audit investigasi terhadap mempunyai legalitas sebagaimana diatur dalam modus operandinya sederhana dan ruang lingkup tindak pidana korupsinya sempit yaitu sebagai alat bukti surat yang akan bermuara kepada alat bukti keterangan ahli. Selanjutnya narasumber narasumber yang lain mengungkapkan Pidana merupakan pedoman bagi hakim dalam menanggapi berbagai perkara termasuk perkara Tindak Pidana Korupsi Namun hanya sebatas sebagai pedoman kerja yang tidak dapat mengikat Hakim dalam menilai dimana bukan hanya BPK dan BPKP saja melainkan Penyidik Terdakwa dan Hakim pun dapat melakukan audit perhitungan kerugian keuangan negara sepanjang relevan dalam pemeriksaan perkara

\section{Faktor yang Mempengaruhi Jaksa Penyidik Pada Kejaksaan Negeri Denpasar Meminta Bantuan BPKP Untuk Audit Investigasi terhadap Kerugian Keuangan Negara}

Dalam melakukan penyidikan terhadap perkara tindak pidana korupsi Jaksa Penyidik dapat melakukan koordinasi kepada BPKB. Dari nota kesepahaman (MoU) tersebut maka ketika Jaksa Penyidik membuktikan unsur kerugian keuangan negara sebaiknya melakukan koordinasi dan meminta bantuan audit investigasi kepada BPKP. Fakta di lapangan menunjukkan Jaksa Penyidik pada Kejaksaan Negeri Denpasar lebih sering investigasi dalam rangka perhitungan kerugian keuangan Negara. Berdasarkan hasil wawancara yang akukan terhadap Bapak Kepala Seksi Tindak Pidana Khusus I Nengah Astawa S.H selaku Jaksa Penyidik (Senin 26/10/2020 pukul 1000 wita) terdapat beberapa faktor yang mempengaruhi Jaksa Penyidik pada Kejaksaan Negeri Denpasar meminta bantuan kepada BPKP yaitu:

a. Faktor Kebijakan

Untuk memperlancar penyidikan jaksa meminta bantuan audit investigasi kepada BPKP guna memperhitungkan kerugian keuangan negara selain karena nota kesepahaman (MoU) yang telah dilakukan dalam meminta bantuan audit investigasi antara Jaksa Penyidik pada Kejaksaan Negeri Denpasar dengan BPKP Prov Bali telah menjalin silaturahmi yang sangat baik sebelumnya sehingga dapat semakin mudah untuk melakukan komunikasi dan koordinasi terkait perkara yang sedang ditangani

b. Faktor Efisiensi dan Efektivitas

Dalam melaksanakan tugas dan fungsinya untuk mengungkapkan kerugian keuangan negara yang modus operandinya sederhana dan ruang lingkup tindak pidana korupsinya sempit. Jaksa mPenyidik untuk mempermudah dan mempercepat koordinasi dalam rangka perhitungan kerugian keuangan negara yang mana hasil auditnya Berbeda halnya dengan Badan Pemeriksa Keuangan dan ini menjadi bahan pertimbangan nantinya saat persidangan.

c. Faktor Sumber Daya Manusia

Jaksa Penyidik atau penyidik pada umumnya mempunyai payung hukum untuk melakukan penghitungan sendiri atas pertimbangan Mahkamah Konstitusi yang telah mempertimbangkan bahwa Komisi Pemberantasan Korupsi (KPK) (termasuk didalamnya penyidik dan jaksa penyidik) bukan hanya dapat berkoordinasi dengan modus operandinya sederhana dan ruang lingkup tindak pidana korupsinya sempit masih dimungkinkan untuk dilakukan penghitungan kerugian keuangan negara sendiri oleh Jaksa Penyidik. Untuk itu pengungkapan kerugian keuangan negara yang modus operandinya sederhana dan ruang lingkup tindak pidana korupsinya sempit, namun dalam upaya mengungkap adanya kerugian keuangan negara yang sifatnya komplek dan rumit maka dibutuhkan keahlian khusus untuk melakukan audit investigasi yang hanya dimiliki oleh auditor sehingga jaksa penyidik memerlukan bantuan dari auditor BPKP.

\section{SIMPULAN DAN SARAN}

\section{Simpulan}

Berdasarkan dari apa yang telah diuraikan dalam pembahasan sebelumnya maka dapat disimpulkan bahwa Untuk mengungkap kerugian dapat dilakukan dengan mudah mempunyai legalitas dan keabsahannya memenuhi unsur-unsur Pasal 184 KUHAP dimana hasil audit investigasi dalam pembuktian unsur kerugian keuangan negara pada perkara tindak pidana korupsi memiliki peran yaitu sebagai alat bukti surat, bukti Petunjuk dan bukti keterangan ahli yang kedua kecenderungan Jaksa 
Penyidik pada Kejaksaan Negeri Denpasar untuk melakukan audit investigasi terhadap Badan Pengawas Keuangan dan Pembangunan disebabkan oleh faktor kebijakan efisiensi dan efektivitas serta faktor sumber daya manusia.

\section{Saran}

Berdasarkan hasil penelitian adapun yang menjadi saran adalah Agar diatur kewenangannya dalam membantu tugas konstitusi yakni dengan merubah lebih lanjut dengan Undang-Undang Sehingga legalitas tidak menjadi perdebatan panjang lagi dan tentunya dengan bantuan Badan Pengawas Keuangan dan Pembangunan (BPKP) yang telah mempunyai legal standing kuat akan dapat membantu dalam melakukan pemeriksaan terhadap tata kelola dan tanggung jawab penggunaan keuangan negara, yang kedua diharapkan Jaksa Penyidik memberikan tembusan Surat Permohonan kepada Badan Pemeriksa keuangan (BPK) mengingat yang secara konstitusional memiliki kewenangan dalam hal tersebut adalah Badan Pemeriksa Keuangan (BPK) dan juga hasil audit investigasi terhadap ditembuskan ke Badan Pemeriksa Keuangan (BPK).

\section{DAFTAR PUSTAKA}

Amania, N. (2016). Kewenangan Penghitungan Kerugian Keuangan Negara dalam Kasus Tindak Pidana Korupsi di Indonesia. Jurnal Syariati, 2(9), 311-324.

Ferdian, . Bayu, Din, M., \& Gaussyaah, M. (2018). Penetapan Kerugian Negara dalam Perkara Tindak Pidana Korupsi. Journal Law, 2(3), 320-337.

Ferry, M. H. (2014). Kerugian Keuangan Negara. Thafa Media. Makawimbang Hernold Ferry 2014

Imron, R. M. (2016). Wewenang Badan Pemeriksa Keuangan dan Badan Pengawasan Keuangan dan Pembangunan dalam Menilai Kerugian Keuangan Negara. Jurnal Ilmu Hukum, 26-53.

Koswara, I. Y. B. dan B. menghitung K. K. N. dalam R. P. P. K. (2019). Kebijakan Hukum Pidana terhadap Perhitungan Potensi Kerugian Keuangan Negara. Jurnal Ilmiah Hukum, 4(1).

Permana, ri C. I. (2018). Wewenang Badan Pengawas Keuangan dan Pembangunan (BPKP) Menghitung Kerugian Keuangan Negara. Jurnal Hukum Peratun, 1(1), 101-118.

Romli, A. (2004). Sekitar Masalah Korupsi Aspek Nasional dan Aspek Internasional. Mandar Maju.

Soerjono, S., \& Mamudji, S. (2015). Penelitian Hukum Normatif Suatu Tinjauan Singkat. Grafindo Persada.

Undang-Undang Nomor 20 Tahun 2001 tentang Perubahan Atas Undang-Undang Nomor 31 Tahun 1999 Tentang Pemberantasan Tindak Pidana Korupsi

Putusan Mahkamah Konstitusi Nomor 31/PUU-X/2012 tanggal 23 Oktober 2012

Surat Edaran Mahkamah Agung (SEMA) Nomor 4 Tahun 2016 